\title{
A melancolia conjunta escrita com a tinta em primeira pessoa
}

The collective melancholia written with the first person pencil

\section{Matheus Cosmo}

Matheus Cosmo

Mestrando do Programa de Pós-Graduação em Artes Cênicas da Escola de Comunicações e Artes da Universidade de São Paulo (ECA-USP).

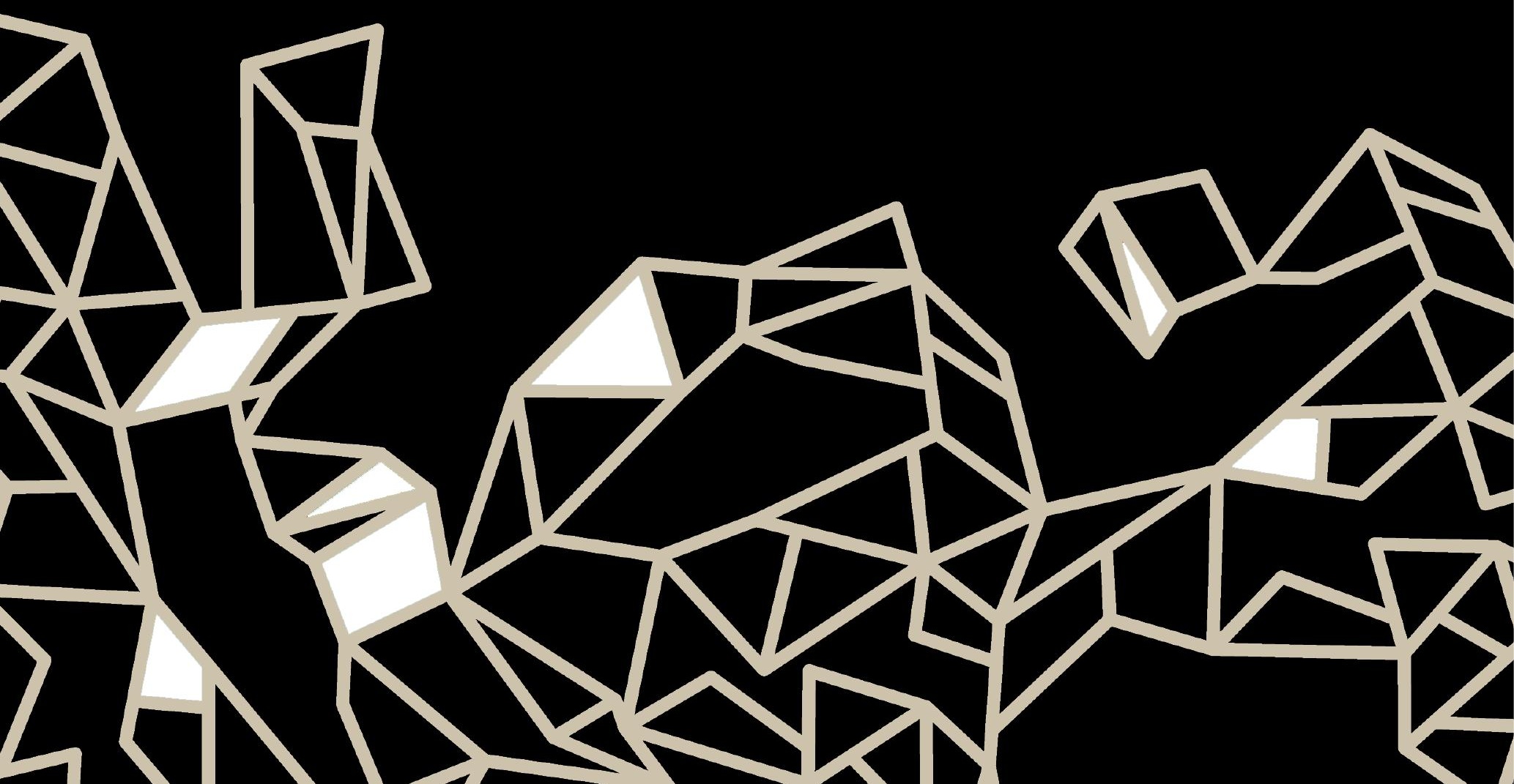




\section{Resumo}

Este texto nasce de uma constatação frequentemente reiterada em análises acerca da atual conjuntura política nacional: o poder, organizando-se a partir da ideia de crise, melancolizou grande parte das subjetividades emergentes. Sendo esse um enunciado verdadeiro, busca-se aqui, por meio de preceitos advindos, em grande parte, da filosofia e da psicanálise, a redescoberta de uma potência intrínseca à melancolia, capaz de reavaliar os impasses que inflamam o Brasil atual.

Palavras-chave: Melancolia, Contemporaneidade, Política.

\section{Abstract}

This text comes from a proposition frequently repeated in current national political situation analysis: the power, organizing itself by the idea of crisis, melancholized a great deal of the emerging subjectivities. This being a true statement, it is sought here, through precepts arising, largely, from philosophy and psychoanalysis, the rediscovery of an intrinsic power to melancholy, able to reassess the impasses that rouse in the current Brazil.

Keywords: Melancholia, Contemporaneity, Politics.

Teimar em permanecer parecia absurdo. Havia poucas possibilidades de uma mudança de vento. Era preciso tomar uma decisão rápida. Voltar para casa agora já não seria possível. [...] Nesse transe doloroso, partir parecia tão impossível quanto ficar.

Thomas Mann

Em um de seus mais famosos poemas, "A flor e a náusea", publicado em seu expoente livro de 1945, Carlos Drummond de Andrade propagou um de seus mais conhecidos enunciados: "Não, o tempo não chegou de completa justiça./ O tempo é ainda de fezes, maus poemas, alucinações e espera" (ANDRADE, 2015, p. 106). Anos mais tarde, em 1991, Italo Calvino esboçaria a certeza de que "o dia de hoje pode ser banal e mortificante, mas é sempre um ponto em que nos situamos para olhar para a frente ou para trás" (CALVINO, 1993, p. 14). Alguns diriam que esta é a origem da sempre escassa atitude analítica frente ao contemporâneo, dado que é resultante de uma aposta na qual o sujeito en- 
contra-se completamente imerso. Há quem diga que, por essa razão, as análises sobre o tempo presente tendem a se mostrar razoavelmente enfadonhas, uma vez que revelam a impossibilidade de distinguir aquilo que é essencial do que é certamente supérfluo. Entretanto, isso não indica ou exprime uma necessidade de abandono do tempo presente. Ao contrário, elevá-lo ao pensamento parece ter sido um dos grandes objetivos do raciocínio dialético, uma vez que, conforme ressaltou Bataille, em 1947, "em cada coisa, tanto na seta quanto nas figuras espectrais da poesia, o passado, o presente e o futuro concorrem para a determinação do sentido"' Talvez, encontre-se aqui um possível resultado desta complicada concorrência.

Tornou-se comum, em análises acerca da conjuntura política atual, enfatizar a irrupção de uma grande dose melancólica nas presentes configurações subjetivas. Junta-se a esse enunciado a constante repetição de um mesmo e único vocábulo: crise. Ao que tudo indica, a ideia de crise não se apresenta mais como um problema frente ao qual é preciso pensar algumas resoluções, mas se revela como a própria forma de manifestação, organização e manutenção do poder. Não por menos, um dos grandes slogans apresentados pelo então "presidente" (há que se colocar aspas) Michel Temer foi a máxima, espalhada em vários cantos do país: "Não pense em crise, trabalhe". Em linhas gerais, trabalhar já é uma contribuição para o próprio funcionamento da crise. Diriam os integrantes do Comitê Invisível que "não vivemos uma crise do capitalismo, mas, pelo contrário, o triunfo do capitalismo de crise" (COMITÊ INVISÍVEL, 2016, p. 27) - e, como afirmou a psicanalista Julia Kristeva, "em tempos de crise, a melancolia se impõe, é expressa, faz sua arqueologia, produz suas representações e seu saber" (KRISTEVA, 1989, p. 15).

Antes de prosseguir a análise em torno da melancolia, que estrutura todo o argumento interno deste texto, um importante apontamento mostra-se necessário. Poder-se-ia dizer que, ao menos desde a segunda metade do século passado, a ideia de crise também se tornou um importante denominador nas

1 A sentença discriminada foi publicada pela primeira vez na revista Critique, em uma análise intitulada "Baudelaire 'mis à nu': l'analyse de Sartre et l'essence de la poésie". Dez anos depois, o texto seria revisado e publicado no livro La littérature et le mal, traduzido recentemente para o português, por Fernando Scheibe, como A literatura e o mal. 
análises teatrais - um resultado direto da Teoria do drama moderno, de Peter Szondi. Embora seja contrário a algumas das propostas do húngaro, Jean-Pierre Sarrazac sugere uma operação analítica que alguns poderiam julgar perspicaz, em sua introdução ao Léxico do drama moderno e contemporâneo: que a ideia de crise seja mantida no âmago da própria estrutura dramática, instaurando "uma crise sem fim, nos dois sentidos do vocábulo. De uma crise permanente, de uma crise sem solução, sem horizonte preestabelecido. De uma crise inteiramente em imprevisíveis linhas de fuga" (SARRAZAC, 2012, p. 32). Se a ideia é pertinente ou não, se consegue impulsionar um importante debate acerca da produção dramatúrgica, é outra discussão a ser fortalecida. Aqui, caberia apenas relembrar o diagnóstico fornecido pelo Comitê Invisível: "Tivemos uma fé cega na crise, uma fé tão cega e tão antiga que não percebemos a ordem neoliberal fazer da crise uma peça-chave do seu arsenal" (COMITÊ INVISÍVEL, 2016, p. 23). A verdadeira raiz do problema aqui enfatizado talvez se encontre adormecida em algumas posteriores páginas do livro organizado por Sarrazac, quando o leitor percebe que, para o autor, a crise das relações intersubjetivas é apenas uma etapa necessária para a descoberta de uma nova qualidade de diálogo. ${ }^{2} \mathrm{~A}$ fim de encerrar esta pequena observação e retornar à discussão inicial, seria preciso realçar: quando, depois de atravessado um imenso percurso, se retorna ao mesmo ponto de onde se partiu, pode-se afirmar que a viagem não foi das melhores possíveis - quando a saída de uma crise aponta exatamente para os mesmos lugares nos quais ela parece ter se originado, nenhuma potência efetivamente transformadora conseguiu manifestar-se por completo. Nestes termos, mostra-se possível afirmar que todas as perspectivas acerca de uma suposta crise tornaram-se apenas uma fonte de abstração, um fantasma que, brilhantemente, conseguiu desviar os olhares e espantar aquilo que poderia constituir uma verdadeira crise, potencialmente capaz de reorientar todos os paradigmas. Como se percebe, instaura-se um problema, em algum lugar. Deixo a outrem sua resolução.

2 Em suas palavras: "Talvez a impulsão do monólogo no teatro moderno e contemporâneo, essa tendência do monólogo a suplementar o diálogo interpessoal, não tenha sido senão o sintoma de um fenômeno mais fundamental: reconstruir o diálogo sobre a base de um verdadeiro dialogismo". Esta declaração encontra-se no verbete intitulado "Diálogo (crise do)", escrito pelo próprio Sarrazac, no livro aqui já mencionado. 
O esboço de qualquer consideração acerca da melancolia, de imediato, leva o leitor ao encontro com um conjunto de três textos, escritos diante dos impactos e impasses próprios à Primeira Guerra Mundial: $A$ transitoriedade, Considerações atuais sobre a guerra e a morte e o famoso Luto e melancolia - expoentes da chamada metapsicologia freudiana. É certo que a relação entre luto e melancolia já havia sido feita por Freud em 1910, por exemplo, em uma palestra perante a Sociedade Psicanalítica de Viena, posteriormente intitulada Contribuições para uma discussão acerca do suicídio. Contudo, aqui se encontra em questão, em especial, o último daqueles três textos, publicado apenas em 1917, cuja leitura talvez se revele fundamental para o entendimento das propostas aqui enunciadas. São alguns os pontos que aqui serão objeto de interesse, sem que haja a busca por uma completa e exata demarcação analítica, uma vez que foi o próprio Freud quem classificou como oscilante a definição conceitual de melancolia. De sua análise, dois são os principais eixos que interessam a este texto. Abaixo, o primeiro:

Por fim, devemos notar que o melancólico não se comporta inteiramente como alguém que faz contrição de remorso e autorrecriminação em condições normais. Falta a ele, ou pelo menos não aparece nele de um modo notável, a vergonha perante os outros, que seria sobretudo característica dessas condições. No melancólico, quase se poderia destacar o traço oposto, o de uma premente tendência a se comunicar, que encontra satisfação no autodesnudamento. (FREUD, 2011, p. 55)

Por uma incrível coincidência, autodesnudamento parece ser uma das palavras norteadoras de grande parte das práticas do teatro contemporâneo. Em todos os cantos, encontram-se relatos que se bifurcam entre ideias como autoescritura e autobiografia, por exemplo. Ao que tudo indica, esse autodesnudamento tende a ser uma das premissas do chamado teatro performativo - exatamente porque também constituía o fundamento de grande parte das manifestações da performance art, no século passado. À primeira vista, um encaminhamento óbvio - contudo, perigoso - seria sugerir que a eclosão de cenas em primeira pessoa, no início deste século, para além de traduzir uma completa crise de representatividade em todos os campos, apenas reafirma nossa comum sensação de impotência, reforçando, mesmo que indiretamente, "este gosto podre de fracasso, este travo de derrota sem nobreza" (ABREU, 
2015, p. 36), como descreveu Caio Fernando Abreu em um de seus contos. Não por acaso, ao pensar em caminhos possíveis para o fortalecimento das lutas de esquerda, o inglês T. J. Clark não hesita em dizer: "chega de Rimbaud - chega de apodícticas exposições de entranhas, chega de denúncias exultantes" (CLARK, 2013, p. 34).

Compreendendo que é intrínseco ao neoliberalismo o uso oportuno das liberdades individuais, regidas pelo grande slogan de uma autoexposição, que apenas favorece e impulsiona uma constante autoexploração, seria preciso questionar a verdadeira potência política dessas exposições, transfiguradas em cena - afinal, sabe-se que, menos do que uma possível e imensa estrutura externa, o neoliberalismo é, antes, um modo de subjetivação e produção de novos sujeitos. ${ }^{3}$ Contra vários discursos que, recentemente, ocupam lugar de destaque nas análises dessas obras, poder-se-ia sugerir que a comoção ou identificação alavancada por esses trabalhos cênicos seria apenas o encontro de uma zona emergente de nosso fracasso político-social: um laço que se estabelece a partir de uma melancolia conjunta. Certa vez, quando escrevia uma análise acerca da peça Esperando Godot, de Samuel Beckett, Gilda de Mello e Sousa reconheceu a existência de um mecanismo que talvez também se encontre na base da recepção de grande parte das obras autobiográficas: "a solidariedade que estabelece com o próximo é feita menos de compreensão que do medo de encarar a si próprio" (SOUZA, 1980, p. 126). É provável que fosse por esse motivo que Foucault tanto insistia que, em vez de uma busca incessante em torno da própria subjetividade, contornada e instaurada por supostos processos de identificação e espelhamento, "talvez, o objetivo hoje em dia não seja descobrir o que somos, mas recusar o que somos" (FOUCAULT, 1995, p. 239) - até mesmo porque subjetividades são sempre frutos de mecanismos de poder. Foi em meio a essas asserções que o professor Tomaz Tadeu da Silva ressaltou: "O sujeito não 'existe': ele é aquilo que fazemos dele. Subjetividade e relações de poder não se opõem: a subjetividade é um artefato, é uma criatura, das relações de poder; ela não pode, pois, fundar uma ação contra o poder" (SILVA, 1998, p. 10). Alguns po-

3 Neste aspecto, vale ressaltar o importante livro de Pierre Dardot e Christian Laval, recentemente publicado pela Editora Boitempo, intitulado A nova razão do mundo: ensaio sobre a sociedade neoliberal. A tradução foi feita por Mariana Echalar. 
deriam julgar tal declaração demasiadamente problemática: não poderia uma subjetividade fundar uma ação contra o poder? Então, seria preciso relembrar que mesmo Rosa Parks, com seu singelo I shall not be moved, ao desencadear um processo de luta coletiva, não tomava como ponto de partida apenas a manifestação de uma verdade subjetiva: antes de tudo, sua ação se voltava contra uma estrutura excludente e plenamente racista. Em linhas gerais, é provável que a potência de contestação dos espaços ainda persista enquanto eles não se transformarem por completo em meros depósitos de inquietações individuais - até mesmo porque grande parte dessas inquietações tende a instaurar uma sequência de meros reajustes na relação que se estabelece com o Outro; um ajuste com as normas e práticas de governo, independentemente do viés escolhido, podendo impulsionar uma incorporação de todos os preceitos em jogo ou abrir espaço a uma zona delicada de contestação. Diante disso, uma primeira tarefa seria a de imaginar novas configurações aos processos de criação: e se, ao invés de reviver e reorganizar passadas experiências individuais, um dos argumentos que constitui a base dos fenômenos autobiográficos, o teatro se ocupasse em fundar e formular novas qualidades de experiência coletiva? Certo: alguém poderia relembrar que há sempre uma relação dialética entre o singular e o universal, entre o objetivo e o subjetivo. Tomando essa afirmação como um pressuposto, poder-se-ia enfatizar que as manifestações em primeira pessoa deveriam sempre ter em mente aquilo que, para Adorno, constituía o fundamento e o paradoxo da lírica: no mais íntimo da voz que diz eu, encontram-se todas as estruturas que organizam a sociedade a que ela pertence. Foi assim que, diante da famosa questão de Giorgio Agamben, “O que é o contemporâneo?”, o Comitê Invisível esboçou uma resposta: a época presente é "o que encontramos no fundo de nós mesmos, quando aceitamos descer até lá, quando interrogamos aquilo que vivemos, vemos, sentimos, percebemos" (COMITÊ INVISÍVEL, 2016, p. 16). Mas o fundo de nós mesmos nunca é fundo demais para não suspeitarmos que seja mera superfície. Sendo assim, o contemporâneo fica sendo inapreensível, porém patente - e o inconsciente é a política, diria Lacan. Desse modo, o primeiro ponto, aqui desmembrado, parece ainda não encontrar qualquer margem imediata de resolução. Poder-se-ia dizer que ele permanece em aberto, mas com uma abertura que, de antemão, recusa fracas asser- 
ções que tendem a justificar suas análises por administrações enfadonhas da palavra micropolítica. Não é por que a política encontra-se espalhada em todas as coisas e discursos que qualquer ato possuirá reverberações políticas eficazes, que quaisquer manifestações poderão ser equiparadas com base em possíveis instrumentos comuns de análise. Expansão tal da ideia de política pode acabar acarretando a exclusão de qualquer significado intrínseco ao termo: "qualquer palavra que abranja tudo perde o seu valor e degenera em um som vazio" (EAGLETON, 1997, p. 21). Aparentemente, o que aqui se encontra em jogo são possibilidades de alteração no campo objetivo, que incorpora, restringe e formula o particular. Seria a ênfase na singularidade da dimensão subjetiva apenas mais uma das estratégias neoliberais de destruição e destituição da experiência comum? Se sim, muita confusão já parece ter sido feita nas cabeças e discursos daqueles que acreditaram que a irrupção e exposição de numerosas zonas de suposta intimidade acarretaria a fundação de um novo corpo social. A relação que se iniciava a partir de um pressuposto par dialético, organizado com base em sua contradição, termina por apresentar seus elementos quase como um par relativamente antagônico, embora não sejam plenamente contrários, mas complementares.

Diante dos argumentos expostos, é importante resgatar um texto escrito por Óscar Cornago no ano de 2008. Naquela ocasião, o pesquisador espanhol estava certo de que a eclosão de um número significativo de cenas em primeira pessoa não chegava a impulsionar a formulação de um verdadeiro discurso político: essas manifestações apenas permitiam "vislumbrar uma postura ética, uma vontade de ação frente ao outro, da qual se tenta recuperar a possibilidade do social em termos menores, não mais da ação revolucionária, com letras maiúsculas, mas sim da ação do eu em frente ao tu" (CORNAGO, 2008, p. 26). É possível afirmar que reside nessa declaração a base de grande parte dos problemas com os quais se defronta este texto. Todavia, antes de chegar ao pontual núcleo das necessárias questões, é pertinente relembrar algumas das considerações de dois grandes autores: Raymond Williams e Augusto Boal. Em relação ao primeiro, aqui se resgata um texto de 1973, intitulado Base and superstructure in Marxist cultural theory. ${ }^{4}$ Para aquele importante expoente da reconhecida

4 Uma versão em português pode ser encontrada em Williams (2011). Contudo, a tradução aqui utilizada é outra. 
New Left, seria possível identificar a existência de duas manifestações distintas frente à cultura dominante: "Há claramente algo que chamamos de alternativa à cultura dominante efetiva, e há algo mais, que podemos definir como oposição, num sentido verdadeiro" (WILLIAMS, 2015, p. 218). É certo que a expressão de ambas as faces culturais depende de circunstâncias histórias. Entretanto, a possibilidade de distinção entre uma forma e outra já é extremamente significativa. Nesse esquema, um dado mostra-se crucial: "em certas sociedades é possível encontrar áreas de vida social nas quais alternativas reais são toleradas" (Ibid.). De fato, sabe-se que, a fim de buscar sua perpetuação pelo maior espaço de tempo possível, o poder tende a se fortalecer incorporando tudo aquilo que se apresenta como simples alternativa. As opções são todas logo absorvidas. Não sem razão, são muitas as vozes que insistem em relembrar as lutas das chamadas minorias, legítimos embates alavancados com afinco principalmente a partir da segunda metade do século XX, que não existirá a almejada igualdade em um sistema que possui como fundamento e estrutura a desigualdade e exploração. Desse modo, acredita-se que, junto a suas pautas e reivindicações, tais lutas deveriam afirmar-se contra o próprio sistema capitalista. Caso contrário, tende a tornar-se cada vez mais comum a enunciação de afirmações como aquela dita por Margareth Rago, por exemplo: "O feminismo está na moda, virou pop" (GARCIA, 2015). E um feminismo pop, porque já incorporado pelos meios e formas da indústria cultural, talvez se apresente como uma das múltiplas faces contrárias a um feminismo integralmente resistente - de modo semelhante, é preciso dizer, para espanto de alguns, que reduzir a política à escrita de "Fora Temer" em copos de café não impulsiona uma verdadeira transformação social. Nestas circunstâncias, abre-se um campo que parece ter como fundamento não mais a plenitude da prática política, mas a pura contradição, a partir da qual apenas um comportamento alternativo e não mais opositor parece ser aceito, mantendo válida e pertinente aquela distinção inicial proposta por Williams. Por fim, essas alternativas, esse grande rol de opções, um verdadeiro mercado de novas ideias e propostas, acabam por validar uma sensação parecida com aquela destacada por Winston Churchill a respeito da democracia: uma vez imersos em uma estrutura capitalista, respirando os ares das práticas e ideias neoliberais, certamente estaríamos diante da pior dentre todas as alternativas possíveis, a despeito de todas as outras. 
Relembrando as palavras de Cornago, aqui estaria em jogo uma arte que abdicou da revolução. Uma arte que carece de oposição, na medida em que se limita ao vislumbre de alternativas em meio às condições já estabelecidas, dentro de uma constante (e necessária, contudo) disputa por Editais e novos contratos. Neste ponto, seria pertinente recorrer às considerações do segundo dos autores mencionados: Augusto Boal, com sua importante declaração registrada em "Que pensa você da arte de esquerda?" (BOAL, 1968). Em pleno ano de 1968, Boal reconheceu três tendências no teatro brasileiro (e todas elas deviam ser logo superadas): uma tendência exortativa, o tropicalismo "chacriniano-dercinesco-neo-romântico" e aquela que mais interessa a este texto: o neorrealismo. Dessa última vertente fizeram parte autores como Plínio Marcos, Jorge Andrade, Gianfrancesco Guarnieri, Oduvaldo Vianna FiIho e outros. Não se trata, aqui, de invalidar a significativa contribuição de todos esses autores ao teatro nacional, mas de reconhecer, como fez Boal, os impasses próprios a seu estilo e modo de composição. Uma vez que essa esta vertente neorrealista apenas reproduz a realidade e, desse modo, não parece encontrar os meios de transformá-la, é possível afirmar que sua "importância seja mais documental do que combativa. E nos dias que correm, o teatro brasileiro carece de combatividade" (Ibid., p. 4). Qualquer semelhança entre o argumento de Boal e o tempo presente apenas corrobora aquilo que Roberto Schwarz declarou na revisão de seu diagnóstico formulado acerca de e durante a ditadura militar: "O leitor verá que o tempo passou e não passou" (SCHWARZ, 1978, p. 61). De fato, parece difícil justificar certa perspicácia política em obras que buscam apenas a reprodução da realidade e de suas previsíveis configurações subjetivas - seria este o paradoxo e limite estético intrínseco àqueles chamados teatros do real? Há algo da ordem de um descompasso em uma cena que possui comum acordo com as configurações de seu tempo. Em recente e rápida conversa com Roberto Zular, uma conclusão pareceu despontar dos pequenos espaços entre um respiro e outro: nós não fazemos arte para reiterar quem somos, mas para descobrir um outro nós de nós mesmos. Ou para desatar os nós. Há sempre algo que escapa desta investigação porque ela não envolve mera reiteração do eu. Ela não visa sujeito nem objeto, mas ela é aquele quase, aquele entre, algo incorpóreo. Embora aqui se defenda a vitalidade da arte com base na matéria que irrompe a partir 
de seus meios, é preciso reconhecer, tal como sugeriu Raymond Williams naquele mesmo texto, que o argumento de que as obras de arte encontram-se sempre ligadas a manifestações de uma cultura emergente, de um prenúncio do porvir, não passa de uma retórica familiar. O raciocínio central tende a ser exatamente o oposto: na medida em que boa parte das obras abdicou de uma profunda oposição para pensar apenas em simples alternativas (o que também já é uma grande tarefa: sempre criar novos eventos e proporcionar novas experiências), seus trabalhos parecem se apresentar como contribuições à cultura dominante - inclusive, ampliando seu domínio e campo de atuação. Se a arte abdica de sua potência revolucionária, ela tende a criar meros procedimentos pontuais que acabam por formatar certas comunidades de ouvintes, exaurindo o teatro de seu caráter público e transformando-o em mera rotina dos fins de tarde dominical - e, diria Walter Benjamin, que a rotina é também causa de melancolia: "Pois estar sujeito à rotina significa sacrificar suas idiossincrasias, abrir mão da capacidade de se enojar. $E$ isso torna as pessoas melancólicas" (BENJAMIN, 2012, p. 78). Há que se reconhecer: não foi apenas a arte que, neste início de século, abandonou a ideia de revolução. Este abandono traduz, por completo, uma parte dos setores de esquerda. Basta lembrar que o programa do Partido dos Trabalhadores, em 1990, declarava que o capitalismo é um sistema intrinsecamente antidemocrático e que, por isso, haveríamos de lutar pelo socialismo - uma declaração que talvez possa soar como uma ótima piada aos atuais dirigentes do partido. Não à toa, em recente texto acerca do golpe que encerrou seu primeiro ciclo no dia 31 de agosto de 2016, ${ }^{5}$ Michael Löwy (2016) enfatizou a necessidade de se erguer, novamente, a bandeira socialista. Certamente, alguns diriam que esta ideia tende a mostrar-se razoavelmente antiquada ao tempo presente.

5 A ideia de que o atual golpe, contra o governo de Dilma Rousseff, as bases da recente democracia nacional e boa parte dos direitos conquistados e assegurados pela Constituição de 1988, apenas finalizou o primeiro de seus ciclos com os episódios do dia 31 de agosto de 2016 e a consumação do impeachment pelo Senado Federal implica apontamentos semelhantes àqueles feitos por Guilherme Boulos (2016): "o dia de hoje [o texto foi publicado exatamente no dia 31] não marca a conclusão de um golpe, mas seu início. O golpe contra a soberania do voto popular anuncia o golpe mais duro da história recente contra a maioria do povo brasileiro. Esta agenda não foi eleita e jamais o seria. Só pode ser aplicada com um cerceamento da democracia, pela anulação do voto popular. [...] da mesma forma que o golpe está apenas começando, a resistência também está:. O otimismo com que finalizou sua declaração logo seria eliminado pelo próprio desenvolvimento político da vida nacional. Por vezes, a euforia se converte em silêncio... 
Contudo, é importante resgatar uma declaração de Iná Camargo Costa, anteriormente publicada no Jornal Brasil de Fato, mas atualmente fora do ar: o problema "não é reiterar que 'o projeto socialista está tão fora de pauta', mas discutir por que as organizações políticas, tanto partidos quanto movimentos, não o colocam em pauta. Em outras palavras, desmascarar as organizações políticas que, ao insistir no ponto, continuam empurrando com a barriga a ação reformista que é, repito, contrarrevolucionária”. Já entre 1969 e 1970, Roberto Schwarz questionava: "Que interesse terá a revolução nos intelectuais de esquerda, que eram muito mais anticapitalistas elitários que propriamente socialistas?" (SCHWARZ, 1978, p. 92). Talvez, nenhum. Contudo, isto é algo que aqui não cabe confirmar ou vislumbrar. Por ora, basta-nos a lembrança de uma carta de Marx a Engels, escrita em 10 de junho de 1859:

\section{Querido Frederick:}

Recebi hoje dois manuscritos. Um magnífico, o teu sobre fortifications, mas a propósito do qual sinto remorsos na consciência por ter utilizado o teu escasso tempo livre. O outro, grotesco: uma réplica de Lassalle à minha e à tua crítica ao Sickingen. Uma verdadeira floresta de páginas ineptas, ineptas. É incompreensível como, nesta estação do ano e no meio desses acontecimentos históricos, alguém encontre não só o tempo necessário para produzir semelhantes coisas, mas ainda para pretender que nós o tenhamos para lê-las.

K. M. (MARX, 2012, p. 81)

O segundo dos pontos a ser destacado das propostas freudianas é o que segue:

Também o comportamento dos doentes fica agora muito mais compreensível. Para eles, queixar-se é dar queixa no velho sentido do termo; eles não se envergonham nem se escondem, porque tudo de depreciativo que dizem de si mesmos no fundo dizem de outrem. E estão bem longe de dar provas, perante os que os cercam, da humildade e da submissão que conviriam a pessoas tão indignas; pelo contrário, são extremamente incômodas, mostrando-se sempre como que ofendidos e como se uma grande injustiça tivesse sido cometida contra eles. Tudo isso só é possível porque as reações da sua conduta provêm sempre da constelação psíquica da revolta, que depois, em virtude de um certo processo, se transportou para a contrição melancólica. (FREUD, 2011, p. 59-61) 
Se tudo que um melancólico diz acerca de si é a expressão de uma verdade que o ultrapassa e que diz respeito, fundamentalmente, ao objeto que Ihe foi retirado, alguém poderia afirmar que boa parte daqueles impasses autobiográficos, aqui já apresentados, encontra sua respectiva margem de resolução com uma simples operação: no discurso, a primeira pessoa transforma-se em, ou pode ser interpretada como, terceira. Entretanto, a própria dinâmica melancólica não permite tão simples deliberação, por um motivo: "não podemos discernir com clareza o que se perdeu e com razão podemos supor que o doente também não é capaz de compreender conscientemente o que ele perdeu" (Ibid., p. 51). Se aquele procedimento discursivo apresentado fosse considerado legítimo, uma necessária problematização acarretaria o surgimento de um preciso questionamento: que voz é essa que emana do discurso e qual seu intrínseco referente? Afinal, o que foi que se perdeu? Em uma de suas análises acerca do romance europeu do século XIX, especialmente os escritos por Jane Austen, George Eliot, Balzac e Flaubert, o crítico italiano Franco Moretti percebeu que já não eram os sujeitos nem os narradores quem falavam, mas era uma terceira voz que emanava do discurso: a voz do contrato social, do indivíduo socializado (MORETTI, 2003). Talvez, neste estágio do capitalismo, cuja ênfase desmesurada na ideia de subjetividade revela apenas um profundo apagamento da potência subjetiva e a plena destruição da noção de comunidade, a voz que emana dos discursos seja apenas o resquício de uma subjetividade agonizante, que compreende o fim de uma civilização, mas não consegue vislumbrar um novo caminho, instaurando uma dinâmica semelhante àquela descrita por Kristeva: "tudo findou ele parece dizer, mas eu permaneço fiel a esta coisa finda, estou colado a ela, não há revolução possível, não há futuro..." (KRISTEVA, 1989, p. 61) - o que chega a parecer uma paráfrase daquilo que foi o grande lema de Margaret Thatcher: there is no alternative. Não por menos, já em 1930, Walter Benjamin descrevia o que considerou como a última das metamorfoses da melancolia em sua história de dois mil anos: sua última transfiguração se revelou por meio de uma estupidez torturada. Em suas palavras: "Hoje as pessoas afagam distraidamente essas formas ocas. [...] Nunca ninguém se acomodou tão confortavelmente numa situação tão desconfortável” (BENJAMIN, 2012, p. 79). 
Nasce disso o peculiar e instigante diagnóstico fornecido pelo filósofo grego Kostas Axelos:

\begin{abstract}
"Nossa" sociedade - nossa civilização, nossa cultura - parece tão sólida através de todas as fissuras e aberturas, crises e disfunções - que parece que não podemos mais movê-la. Ela é que nos move, sobre trilhos estabelecidos que não excluem absolutamente os descarrilamentos. Algumas correias de transmissão se quebram. Com efeito. Mas o vazamento continua. $E$ há redes de informação que se fortalecem. Será o nada que acontece -a conquista do nada devendo ainda ser empreendida - ou nada mais acontece? O que não quer dizer que tudo esteja parado. (AXELOS, 1983, p. 92)
\end{abstract}

Dois são os espaços abertos pelo autor. Cabe ocupá-los.

Talvez não haja outra maneira mais exata de iniciar esta discussão a não ser pelos versos do poeta Sergio Cohn: "Sempre que acreditei/ que não havia nada acontecendo/ descobri que era eu/ que estava no lugar errado" (COHN, 2015, p. 16). Há sempre uma potência, ainda não classificada nem mensurada, que se locomove nos mínimos espaços de silêncio - uma força que, certa vez, Clarice Lispector disse ser o centro de toda sua busca. Dada a certeza dos eventos, seria preciso averiguar em que medida eles constituem verdadeiros acontecimentos. Neste sentido, embora se mostrem potencialmente arbitrários e questionáveis, os textos do filósofo coreano Byung-Chul Han parecem ganhar cada vez mais espaço no centro de debates e discussões. Um exemplo disso ocorreu no dia 4 de julho de 2016, quando Eliane Brum dedicou sua coluna no Jornal El País para divulgar uma grande resenha do livro Sociedade do cansaço, publicado pela Editora Vozes no ano passado. Inspirada pelas ideias formuladas por Han, foi Brum quem enunciou o seguinte - e necessário - questionamento:

Talvez parte do que acreditamos ser ativismo seja, ao contrário, passividade. Um novo tipo de passividade, cheia de gritos, de certezas e de pontos de exclamação. Os espasmos tornaram-se a rotina e, ao se viver aos espasmos, um espasmo anula o outro espasmo que anula o outro espasmo. Quando tudo é grito não há mais grito. Quando tudo é urgência nada é urgência. Ao final do dia que não acaba resta a ilusão de ter lutado todas as lutas, intervindo em todos os processos, protestado contra todas as injustiças. Os espasmos esgotam, exaurem, consomem. Mas não movem. Apaziguam, mas não movem. Entorpecem, mas será que movem? (BRUM, 2016) 
$\mathrm{E}$, se movem, seus impulsos nos conduzem a quais territórios? $\mathrm{E}$ para quê nos conduzem a tais lugares? Quais são os projetos em jogo? É certo que cada novo acontecimento produz imprevistas configurações subjetivas. Contudo, talvez esta também seja uma das lições herdadas dos episódios de junho de 2013: embora o respeito absoluto ao coletivo e a negação de qualquer porta-voz individual (e até mesmo da própria individualidade, levando um dos manifestantes à emblemática afirmação de que "eu sou ninguém") tenham aberto um novo campo ético para se repensar a política, "ao, coerentemente, recusar uma prática que impusesse desde o alto o sentido das mobilizações, o MPL [Movimento Passe Livre] as abriu para visões de mundo muito diferentes da sua" (SINGER, 2013, p. 33) - "o que havia sido um movimento da nova esquerda passou a ser um arco-íris, em que ficaram juntos desde a extrema-esquerda até a extrema-direita" (Ibid., p. 34), conforme ressaltou André Singer, em sua pioneira análise. Um legítimo movimento havia levado mais de um milhão de pessoas às ruas para, logo em seguida, acabar se perdendo em meio à multidão, do mesmo modo como boa parte dos discursos utilizados para interpretar as manifestações também acabou se perdendo em um mar de expressões que pouco traduzia aquilo que as ruas exultavam. Na época - mais especificamente, em 27 de junho de 2013 -, Marilena Chauí publicou um texto intitulado "As manifestações de junho de 2013 na cidade de São Paulo". Seguindo suas considerações, mostrava-se possível reconhecer certa perspicácia do movimento em sua ação explícita de politizar suas reivindicações e demandas, ao invés de traduzir tal politização por meios simbólicos, como seria o caso de um quebra-quebra, por exemplo. Se a afirmação da filósofa for verdadeira e, de fato, o MPL tiver conseguido politizar suas pautas, será necessário reconhecer, portanto, que, já em 2013, se revelava uma completa insuficiência e falência estratégica da esquerda nacional. Talvez, não em relação à sua luta; mas aos seus discursos, certamente. Também naquele instante já se encontrava anunciada a necessidade do fim de uma política de conciliação, tal como aquela empregada enfaticamente durante o período lulista. Três anos depois, no dia 31 de agosto de 2016, Gilberto Maringoni, diante do impeachment de Dilma Rousseff, escreve uma nota em sua página em uma rede social: 


\section{FIM DE UM CICLO}

Fim de uma Era.

Fim de uma política de conciliação.

Fim da ilusão de país do jeitinho.

Fim da bobagem letrada do "homem cordial".

Fim da lorota da malemolência e da terra das oportunidades.

Mas não há do que se lamentar, apesar da tristeza reinante.

Houve opções, houve excesso de autoconfiança, houve mitomania.

$O$ certo é que acaba aqui a ingenuidade.

Um risco de giz deve ser traçado neste 31 de agosto.

Qual o novo ciclo?

Não é possível saber. Não há futurologia possível.

Uma coisa dá para antever, para o mal e para o bem.

Abre-se a Era do enfrentamento.

Não seria boa parte dessas afirmativas, principalmente todas aquelas que abrem a nota, descrevendo o término de uma prática e situação, decorrências diretas daquelas imprevisíveis e certamente contraditórias manifestações? Se a resposta for afirmativa, então seria preciso reconhecer uma completa paralisia nacional desde aqueles episódios de 2013 - uma afirmativa que imagino que arrancaria o apoio de alguém como Vladimir Safatle, por exemplo. Uma paralisia que também parece se expressar na completa incapacidade criativa de formular novos enunciados e proposições. Basta pensar que, enquanto o governo nacional retoma a grande máxima positivista de "Ordem e Progresso" (sem o amor como princípio, obviamente), frentes nacionais parecem retomar um emblemático e contraditório "Diretas Já!", sempre agarrando uma tentativa de comparação entre o momento atual e aqueles episódios que tomaram o país a partir de 1964 - fato que, por consequência, acaba mergulhando os sujeitos em uma plena incapacidade de nomear as especificidades da situação atual a partir de seus inerentes contornos. Em uma palestra no SESC Ipiranga, em junho de 2016, Paulo Arantes já alertava para um uso corrente da palavra golpe que, naquele momento, pouco abarcava as especificidades do acontecimento nacional, a despeito do fato de que o país vivenciava abertamente e explicitamente a elaboração de um golpe. Sendo assim, não haveria como não relembrar as palavras de Žižek (2012): 
"Será que a única escolha que temos é a recordação narcisista e nostálgica de momentos sublimes e entusiastas ou a explicação cinicamente realista do motivo por que as tentativas de realmente mudar a situação tiveram de fracassar?” (p. 129). Diante disso, seria justo resgatar o brilhante questionamento drummondiano: "você marcha, José!/ José, para onde?" (ANDRADE, 2015, p. 97). Ora, retomando alguns dos versos do chileno Alejandro Jodorowsky, relembrados por Sergio Cohn, "se estamos perdidos,/ melhor não andarmos tão depressa" (COHN, 2015, p. 5) - afinal, "este mundo não correria tão depressa se não fosse constantemente perseguido pela proximidade do seu colapso" (COMITÉ INVISÍVEL, 2013, p. 61). Certamente, o ano de 2013 marca a falência de antigas estruturas no território nacional. Em 2016, o Brasil se digladia em um cemitério de zumbis. Entretanto, voltemos ao ponto de partida: a questão de Axelos.

Inspirados por Gérard de Nerval, Michael Löwy e Robert Sayre, a partir de uma análise acerca do romantismo, concluem que são dois os raios que parecem iluminar as configurações sociais, desde o advento da modernidade: a luz que advém da estrela da revolta e a claridade proveniente do sol negro da melancolia - às vezes, com o brilho de uma das luzes ofuscando o luzir da outra. Ora, se nossa revolta se transfigurou na expressão pura de uma negatividade constituinte, talvez seja possível reconhecer um nada no centro do acontecimento - e, como propôs aquele filósofo grego, agora é necessário conquistá-lo plenamente. Nesses termos, seria necessário reavaliar e entender a melancolia, antes de tudo, como uma potência destituinte, capaz de abrir espaço para processos dessubjetivantes que, como ressaltou Alenka Zupančič, apontam para uma descontinuidade no sujeito. Em uma de suas entrevistas, a filósofa eslovena que, junto a Slavoj Žižek e Mladen Dolar, compõe um importante grupo de estudos e de revisão da obra lacaniana ressaltou:

Pegue Deleuze: Para ele o sujeito tem de ser relacionado com algo afirmativo, e então ele pode dar a impressão de que a negatividade é ruim, um "não" para tudo. Mas a negatividade de que estou falando e me esforçando para articular é uma negatividade que, como tal, é a base de algo. Não é como se em primeiro lugar nós nos livrássemos de algo. Pelo contrário, é através dessa negatividade radical que algo aparece. Não é uma escolha: ou você é negativo, você diz não, ou você é afirmativo, você diz sim. Esta é uma maneira ruim de colocá-la. O 
sujeito não é simplesmente negativo ou positivo; ele só pode aparecer ou ter lugar através desta negatividade radical. Não se pode separar os dois.

A destituição é sobre um excedente que sai desta negatividade. É precisamente o ponto mesmo em que alguma novidade emerge através desta destituição, como uma nova possibilidade. (TERADA, 2016)

Este movimento revela-se semelhante àquele descrito por Jean Starobinski, em sua análise acerca de um poema do grande melancólico da vida moderna: Charles Baudelaire. Por meio da leitura de sua obra poética, seria oferecida ao leitor a oportunidade de observar uma curiosa operação: a de "tornar-se outro diante de si mesmo" (STAROBINSKI, 2014, p. 40). Apresentar-se-ia um novo sujeito, emergente de um fundamental espaço de negatividade, que já não se erige apenas a partir daquilo que se pode fazer, mas também - e principalmente - daquilo que se pode não fazer. Exatamente com a mesma percepção com a qual Giorgio Agamben terminou um de seus ensaios: "como é somente a ardente consciência do que não podemos ser que garante a verdade do que somos, assim é apenas a visão lúcida do que não podemos ou podemos não fazer que dá consistência ao nosso agir" (AGAMBEN, 2014, p. 73) - uma percepção que, nas páginas finais de $A$ comunidade que vem, gerou o seguinte diagnóstico: "O espantoso não é que algo tenha podido ser, mas que tenha podido não não-ser" (AGAMBEN, 2013, p. 97). Em sua vinda a São Paulo, em 2003, Žižek destacou que esta é, dentre outras, uma das principais funções da psicanálise no mundo contemporâneo: "não cabe ao psicanalista proibir as pessoas de gozar. Mas ele pode ser o porta-voz da autorização para não gozar. É importante que se possa dizer, publicamente: 'Vocês podem não gozar"' (KEHL, 2015, p. 95). Desta negatividade emerge um potencial criativo: "de resto escrevo/ o que posso/ e o que não posso/ me interessa muitíssimo" (MONTEIRO, 2014, p. 22).

Envolto àquelas manifestações de 2013, em um texto publicado na Folha de São Paulo, Peter Pál Pelbart foi claro ao ressaltar que "certa dessubjetivação é condição para a política hoje" (PELBART, 2013). Sendo assim, seria preciso averiguar se as manifestações autobiográficas não seriam um pouco mais eficazes se, em vez de restaurarem uma memória ou enfatizarem a especificidade de uma determinada configuração subjetiva, apostassem na 
instauração de um novo corpo que, aqui, sequer pode ser nomeado a partir de noções como sujeito e subjetividade, uma vez que tamanhas noções não dariam conta daquilo que explodiria no centro da cena. Nas palavras de Yves Bonnefoy, tratar-se-ia de impulsionar uma profunda "escuta daquilo que, na criação, furta-se a si mesmo, perde-se, ignora-se, não sem antes, contudo, transgredir as formas gastas da consciência." (BONNEFOY, 2014, p. 8). Com base nestas afirmações, alguém logo poderia enfatizar que o que aqui se propõe é apenas um novo projeto que se erige não mais a partir da realidade, mas do Real. Certamente, esta seria uma grande discussão a ser feita. Por ora, basta ressaltar aquilo que o Comitê Invisível reconheceu em seu primeiro livro, de 2007: "Não haverá solução social para a situação presente. Antes de tudo, porque o vago agregado de meios, instituições e bolhas individuais, a que chamamos por antífrase 'sociedade', não tem consistência; segundo, porque já não existe linguagem para a experiência comum" (COMITÊ INVISÍVEL, 2013 , p. 14). Menos do que investigar as entranhas de uma linguagem que já se revela ineficaz em seus processos de simbolização, talvez seja necessário, antes, questionar os pressupostos e as relações que se estabelecem com a linguagem mesma - uma atitude descrita por Adorno como essencial em tempos de barbárie. Nesta revisão da própria linguagem, seria preciso relembrar: "os verdadeiros 'avanços' civilizatórios, quando ocorrem, não são necessariamente avanços da técnica, mas sim avanços nas possibilidades de simbolização do Real” (KEHL, 2015, p. 29).

Abrindo um parêntese: recentemente, o pesquisador espanhol Óscar Cornago publicou um texto intitulado $A$ nuestros enemigos: reflexiones sobre el público (2016). Certamente, a ideia do público como um conjunto de inimigos chama a atenção de grande parte dos leitores. Contudo, seguindo o propósito e as ideias deste texto, seria preciso retomar algumas das considerações brevemente enunciadas por Giorgio Agamben, em 19 de fevereiro de 2007, posteriormente reunidas no texto "O amigo". Ao conceber a amizade a partir de um estatuto ontológico, o filósofo italiano reconhece que todo ser é dividido, "é não-idêntico a si, e o eu e o amigo são as duas faces" (AGAMBEN, 2009, p. 89). Entretanto, este amigo "não é um outro eu, mas uma alteridade imanente na 'mesmidade', um tornar-se outro do mesmo" (Ibid., p. 90). Exatamente por isso, a amizade seria uma prática dessubjetivante no âmago da 
existência. Ela funda uma partilha que carece de qualquer objeto, mas que faz do próprio partilhar sua fonte de experiência e fundamento político. Então, se for preciso repensar grande parte da potência política atual a partir de categorias proeminentes à dessubjetivação, talvez um dos maiores problemas das ideias de Cornago resida já em seu ponto de partida. Fecho esta nota.

Próximo ao término deste texto, há algumas coisas que, talvez, ainda precisem ser ditas. A primeira delas foi enunciada pela primeira vez por John Gassner, em 1960:

Pode-se concluir pela história do pós-guerra que a morte do drama social tem sido exagêro da reportagem crítica e jornalística, mesmo que não se perceba um movimento social de teatro a não ser em países comunistas, onde nenhuma outra filosofia de teatro séria teve alguma chance de sobreviver. Seria surpreendente se nosso teatro contemporâneo pudesse soltar inteiramente as amarras seculares de algum tipo de interêsse social. Há uma circunstância, todavia, que barra tôdas as perspectivas de um retôrno do teatro de tendências sociais: não é provável que os jovens o apóiem. Eles já classificam os adeptos do drama social das décadas de 1930 a 1940 como sentimentais e confusos, e os novos intelectuais parecem estar resolvidos a nunca deixarem transparecer seus sentimentos humanitários. O teatro de tendências sociais sempre foi um teatro da juventude, e não é possível que prospere quando os jovens são velhos. (GASSNER, 1965, p. 67)

É curioso lembrar que a ênfase na juventude e sua valorização também se encontravam presentes nas formulações daquele conhecido como o pai da psicanálise. Em 1926, ao receber uma carta de Ludwig Binswanger, comunicando a morte de um de seus filhos, Freud responde: "Vocês são bastante jovens para superar essa perda, eu não sou mais capaz disso" (FREUD apud PERES, 2011, p. 136). Em oposição, em seu texto $A$ transitoriedade, publicado dez anos antes, de algum modo ainda se revelava um impulso de reconstrução em meio às ruínas: "Sabemos que o luto, por mais doloroso que seja, acaba naturalmente. Tendo renunciado a tudo que perdeu, ele terá consumido também a si mesmo, e nossa libido estará novamente livre - se ainda somos jovens e vigorosos - para substituir os objetos perdidos por outros novos, possivelmente tão ou mais preciosos que aqueles. Cabe esperar que não seja diferente com as perdas dessa guerra" (FREUD, 2010, p. 188). Nessa 
reconstituição, um importante movimento, sempre imprevisto, pode ganhar espaço. Este deslocamento implica a transformação de uma juventude de luto em uma juventude de luta - um fenômeno emergente na França, por exemplo, como propôs Jacques Rancière (2016), a partir de movimentos como o Nuit Debout. No caso brasileiro, análise semelhante poderia ser feita em relação aos protagonistas das ocupações das escolas estaduais, das Fábricas de Cultura e das Fundações Nacionais das Artes, por exemplo. Recentemente, o cineasta Eryk Rocha reconheceu que a destituição de Dilma Rousseff foi também resultante de um processo de acomodação da esquerda - em especial, do Partido dos Trabalhadores. O golpe orquestrado também seria fruto de nossa "falta de imaginação política e poética" (ROCHA, 2016). É curioso relembrar a declaração dada por Rocha porque sua asserção é fundamentalmente contrária à análise que Peter Pál Pelbart desenvolveu em uma carta aberta aos secundaristas, na qual, logo no início do desenvolvimento de seus argumentos, reconhece que "esse movimento [a ocupação de mais de duzentas escolas, no final do ano passado, pelos secundaristas de São Paulo] destampou a imaginação política em nosso país" (PELBART, 2016, p. 5). Assim, emerge o significativo questionamento que impulsiona grande parte das reflexões políticas atuais: efetivamente, em que resulta cada uma das ocupações? Para além dos encontros e do reconhecimento de novas possibilidades de organização de cada um dos espaços ocupados, quais são os rastros deixados e os avanços sugeridos em relação a todo o corpo político-social? No que diz respeito aos secundaristas, por exemplo, se exatos $5,1 \%$ apoiavam o impeachment de Dilma, 45,8\% mostravam-se contrários e 13,9\% apostavam no slogan "Fora todos", o que os outros 35,2\% têm a dizer e sugerir? O que esperar dos $62,3 \%$ que enfatizaram que os movimentos sociais deveriam ser completamente autônomos e independentes de partidos? ${ }^{6}$ Há quem diga que apenas o tempo poderá fornecer esta resposta. Sobre isso, não restam dúvidas. Contudo, a mais comum sequência do argumento anterior implica um perigoso desdobramento, por acreditar que novas subjetividades, radicalmente inéditas, foram produzidas por aquele acontecimento. O perigo reside no fato de que apenas a insurreição não é capaz de produzir novos sujeitos: "A

6 Todos esses dados se encontram disponíveis em: http://gpopai.usp.br/pesquisa/180516/. Acesso: 13 ago. 2016. 
insurreição pode ser a explosão bruta da revolta, mas para que essa revolta forje um sujeito emergente é necessário ainda mais um esforço. Só mais um esforço, se quiserdes ressoar a emergência" (SAFATLE, 2016, p. 14). Este esforço não deve exigir um apagamento total de qualquer rastro melancólico. Quando desenvolveu sua brilhante análise, Freud se esqueceu de levar em consideração toda a tradição que a própria melancolia carrega, já que, em seu histórico, se nota uma qualidade fundamental: a potência criativa que habita entre o gênio e a loucura. Em cada manifestação melancólica, há sempre uma qualidade intrínseca de saber que se encontra oculta. É esta a energia que precisa ser liberada. Talvez, por isso, Kristeva reconheça que "não existe imaginação que não seja, aberta ou secretamente, melancólica" (KRISTEVA, 1989, p. 13).

No fundo, melancolia e arte parecem duas expressões indissociáveis. Embora não seja possível afirmar o que foi que se perdeu, é por meio da arte que este indeterminado objeto pode ser captado e conhecido. Talvez, existam coisas que possam ser possuídas apenas se já estiverem perdidas desde sempre, constituindo aquilo que Hannah Arendt transfigurou como um tesouro perdido e sem nome. Neste sentido, esfumaçam-se as fronteiras entre arte e vida, invadindo o centro da cena certa arte de viver: "A arte de viver é, nesse sentido, a capacidade de nos mantermos em relação harmônica com o que nos escapa" (AGAMBEN, 2014, p. 166). Em outro de seus livros, Giorgio Agamben ressaltou que é apenas por meio da afirmação da perda que tais objetos perdidos podem, enfim, ser efetivamente apropriados pelos sujeitos. Não se trataria apenas de uma perda, incorporação ou apropriação, mas de três operações que ocorrem simultaneamente. Nesse interregno, a realidade se abre como um imenso campo de possibilidades. Em outras palavras, mesmo que fosse orientado por aquela mesma certeza de Baudelaire (1985) - a saber: "[Je pense] A quiconque a perdu ce qui ne se retrouve/ Jamais, jamais!' (p. 328) ${ }^{7}$-, quando dispara contra si, no último ato de $A$ gaivota, Treplev retém Nina a seu lado, para sempre. Nenhum objeto se perdeu. Não é a morte que se encontra em questão: é a plenitude da vida que nos assusta. Como disse Ana Martins Marques, em um de seus singelos poemas: "Ainda

7 "[E penso] Em alguém que perdeu o que o tempo não traz/ Nunca mais, nunca mais!" (BAUDELAIRE, 1985, p. 329). 
que não te fossem dedicadas/ todas as palavras nos livros/ pareciam escritas para você" (MARQUES, 2015, p. 16) - e foram; e ainda são.

Em 26 de novembro de 1885, Friedrich Engels escreveu uma carta à escritora Minna Kautsky, na qual enfatizava que "o autor não está obrigado a apresentar ao leitor a solução histórica dos conflitos sociais que descreve" (MARX; ENGELS, 2012, p. 66). Não há soluções aqui. Há apenas a certeza de que os trabalhos e investigações não se concluem: eles só podem ser abandonados, em certas esquinas, para que outros os conduzam a novos trajetos. Este é o ponto de um abandono. Os espaços deixados em branco circunscrevem o Real.

NOTA: Dias após a finalização da primeira versão deste texto, assisti à peça Nós, do Grupo Galpão, dirigida por Marcio Abreu. Em tempos tão acirrados, de profunda incerteza e inaudita estagnação, um grupo que ocupa palcos e praças por todo o Brasil há trinta e quatro anos volta ao centro da cena para dizer que não há Moscou a nenhum de nós - e muito menos àquele garoto pobre e negro que esperava no ponto de ônibus. Mesmo que não exista o lugar almejado e sua impossibilidade seja motivo de profunda melancolia, algo novo desponta dos quase imperceptíveis espaços de silêncio entre uma nota musical e outra. Grande parte das questões aqui enunciadas ao longo de várias páginas foram discriminadas e presentificadas pelo Grupo, no palco do SESC Consolação. Em um dos momentos do espetáculo, um poema da polonesa Wisława Szymborska foi lido aos espectadores. Naquele poema, um dístico traduzia a imensidão do trabalho apresentado: "Eles próprios não veem/ quanto carregam nas mãos vazias" (SZYMBORSKA, 2011, p. 55). Por vezes, é preciso deixar morrer para que seja possível observar o nascimento daquilo que, apesar de todos e de cada um dos apesares, não cansa de florescer. Ao grupo, aos espectadores e a todos nós, ficam as palavras de Kostas Axelos que, aqui, são apresentadas com esta nota ${ }^{8}$ - há certos conteúdos que não cabem em normas acadêmicas: $O$ pensamento por vir, em que temos de nos introduzir, é inseparável do pensamento de há muito vigente e do pensamento presente - como também do que ainda não foi pensado. É inseparável também da experiência passada, atual e futura. Da experiência do mundo. Trata-se de se

8 Vale dizer, contudo, que o trecho destacado pode ser encontrado no intervalo entre as páginas 9 e 11, em seu livro Introdução ao pensamento futuro (1969). 
promover um pensar o mundo que Ihe corresponda à experiência e à práxis. Que ausculte tanto a prosa como a poesia do mundo. [...] O pensamento por vir não é apenas algo que permanece futuro. Ele já se instalou,já está em vigor e há-de vir ainda. Pode-nos encantar e encorajar mas ao mesmo tempo há-de experimentar e introduzir novas simplificações e unilateralidades. Pertence à nova riqueza e à nova pobreza - que são e permanecem inseparáveis da vida e do amor, da linguagem e do pensamento, do trabalho e das lutas, do jôgo e da morte, sejam êles velhos ou novos. É assim o "vigor"do e no jôgo do tempo que tudo reúne e destrói, repousando em sua totalidade. É assim que joga a errância, cujo jôgo faz descansar no repouso todo movimento.

\section{Referências bibliográficas}

ABREU, C. F. Morangos mofados. 12. ed. Rio de Janeiro: Nova Fronteira, 2015.

AGAMBEN, G. A comunidade que vem. Tradução e notas Cláudio Oliveira. Belo Horizonte: Autêntica, 2013.

Estâncias: a palavra e o fantasma na cultura ocidental. Tradução Selvino José Assmann. Belo Horizonte: UFMG, 2007.

Nudez. Tradução Davi Pessoa Carneiro. Belo Horizonte: Autêntica, 2014.

O que é o contemporâneo? e outros ensaios. Tradução Vinícius Nicastro Honesko. Chapecó: Argos, 2009.

ANDRADE, C. D. Nova reunião: 23 livros de poesia. São Paulo: Companhia das Letras, 2015.

AXELOS, K. Horizontes do mundo. Tradução Lígia Maria Pondé Vassalo. Rio de Janeiro: Tempo Brasileiro; Fortaleza: Universidade Federal do Ceará, 1983.

Introdução ao pensamento futuro: sôbre Marx e Heidegger. Tradução Emmanuel Carneiro Leão. Rio de Janeiro: Tempo Brasileiro, 1969.

BATAILLE, G. A literatura e o mal. Tradução Fernando Scheibe. Belo Horizonte: Autêntica, 2015.

BAUDELAIRE, C. As flores do mal. Tradução e notas Ivan Junqueira. Edição bilíngue. Rio de Janeiro: Nova Fronteira, 1985.

BENJAMIN, W. Magia e técnica, arte e política: ensaios sobre literatura e história da cultura. Tradução Sérgio Paulo Rouanet. Prefácio Jeanne Marie Gagnebin. 8. ed. São Paulo: Brasiliense, 2012.

BOAL, A. Que pensa você da arte de esquerda?. 5 jun. 1968. Disponível em: <https://institutoaugustoboal.org/2012/11/24/que-pensa-voce-da-arte-de-esquerda-augusto-boal/>. Acesso em: 13 ago. 2016. 
BOULOS, G. O golpe está apenas começando. Folha de S. Paulo, 31 ago. 2016. Disponível em: <http://www1.folha.uol.com.br/colunas/guilhermeboulos/2016/08/ 1808926-o-golpe-esta-apenas-comecando.shtml>. Acesso em: 31 ago. 2016.

BRUM, E. Exaustos-e-correndo-e-dopados: na sociedade do desempenho, conseguimos a façanha de abrigar o senhor e o escravo no mesmo corpo. El País, 4 jul. 2016. Disponível em: <http://brasil.elpais.com/brasil/2016/07/04/politica/1467642464_246482.html>. Acesso em: 13 ago. 2016.

CALVINO, I. Por que ler os clássicos. Tradução Nilson Moulin. São Paulo: Companhia das Letras, 1993.

CHAUÍ, M. As manifestações de junho de 2013 na cidade de São Paulo. Teoria e Debate, n. 113, 27 jun. 2013. Disponível em: <http://www.teoriaedebate.org.br/materias/nacional/manifestacoes-de-junho-de-2013-na-cidade-de-sao-paulo?page=full>. Acesso em: 5 set. 2016.

CLARK, T. J. Por uma esquerda sem futuro. Tradução José Viegas. São Paulo: Editora 34, 2013.

COHN, S. Estes tempos. Rio de Janeiro: Megamíni, 2015.

COMITÊ INVISÍVEL. A insurreição que vem. Tradução e diagramação Edições Baratas. Disponível em: <http://www.pucsp.br/ecopolitica/documentos/penalizacao_a_ ceu_aberto/docs/2013-A-insurreicao-que-vem.pdf >. Acesso em: 13 ago. 2016.

Aos nossos amigos: crise e insurreição. Tradução Edições Antipáticas. São Paulo: n-1 Edições, 2016.

DREYFUS, H. L.; RABINOW, P. Michel Foucault: uma trajetória filosófica: para além do estruturalismo e da hermenêutica. Tradução Vera Porto Carrero. Rio de Janeiro: Forense Universitária, 1995.

EAGLETON, T. Ideologia: uma introdução. Tradução Silvana Vieira e Luís Carlos Borges. São Paulo: Boitempo; Universidade Estadual Paulista, 1997.

FREUD, S. Luto e melancolia. Tradução, introdução e notas Marilene Carone. São Paulo: Cosac Naify, 2011.

Obras completas: introdução ao narcisismo, ensaios de metapsicologia e outros textos (1914-1916). Tradução Paulo César de Souza. São Paulo: Companhia das Letras, 2010. v. 12.

GASSNER, J. Rumos do teatro moderno. Tradução Luiza Machado da Costa. Rio de Janeiro: Lidador, 1965.

KEHL, M. R. O tempo e o cão: a atualidade das depressões. 2. ed. São Paulo: Boitempo, 2015.

KRISTEVA, J. Sol negro: depressão e melancolia. Tradução Carlota Gomes. 2. ed. Rio de Janeiro: Rocco, 1989.

LÖWY, M. Da tragédia à farsa: o golpe de 2016 no Brasil. In: JINKINGS, I.; DORIA, K.; CLETO, M. Por que gritamos golpe? Para entender o impeachment e a crise política no Brasil. Ilustrações Laerte Coutinho. São Paulo: Boitempo, 2016. 
LÖWY, M.; SAYRE, R. Revolta e melancolia: o romantismo na contracorrente da modernidade. Tradução Nair Fonseca. São Paulo: Boitempo, 2015.

MARINGONI, G. Fim de um ciclo. 31 ago. 2016. Disponível em: <https://www. facebook.com/gilberto.maringoni/posts/572102836325459>. Acesso em: 5 set. 2016.

MARQUES, A. M. O livro das semelhanças. São Paulo: Companhia das Letras, 2015.

MARX, K.; ENGELS, F. Cultura, arte e literatura: textos escolhidos. Tradução José Paulo Netto e Miguel Makoto Cavalcanti Yoshida. 2. ed. São Paulo: Expressão Popular, 2012.

MONTEIRO, A. Cheguei atrasado no campeonato de suicídio. Juiz de Fora: Aquela, 2014.

PELBART, P. P. Anota aí: eu sou ninguém. Folha de S. Paulo, 19 jul. 2013. Disponível em: <http://www1.folha.uol.com.br/opiniao/2013/07/1313378-peter-pal-pelbart-anota-ai-eu-sou-ninguem.shtml>. Acesso em: 13 ago. 2016.

. Carta aberta aos secundaristas. São Paulo: n-1 Edições, 2016. (Série Pandemia)

RAGO, M. "O feminismo está na moda. Virou pop". Revista Época, 15 nov. 2015. Entrevista concedida a Sergio Garcia. Disponível em: <http://epoca.globo.com/ vida/noticia/2015/11/margareth-rago-o-feminismo-esta-na-moda-virou-pop.html>. Acesso em: 13 ago. 2016.

RANCIĖRE, J. A transformação de uma juventude de luto em uma juventude de luta. Tradução Daniel Alves Teixeira. LavraPalavra, 22 jul. 2016. Entrevista concedida a Joseph Confavreux. Disponível em: <https://lavrapalavra.com/2016/07/22/a-transformacao-de-uma-juventude-de-luto-em-uma-juventude-de-luta/>. Acesso em: 13 ago. 2016.

ROCHA, E. O golpe também é fruto de uma falta de imaginação política e poética. Blog da Boitempo, 4 jul. 2016. Entrevista concedida a Fernando Luiz Salgado da Silva, Maria Fernanda Novo e Jeanne de la Larrard. Disponível em: <https:// blogdaboitempo.com.br/2016/07/04/eryk-rocha-o-golpe-tambem-e-fruto-de-uma-falta-de-imaginacao-politica-e-poetica/>. Acesso em: 13 ago. 2016.

SAADI, F.; GARCIA, S. Próximo ato: questões da teatralidade contemporânea. São Paulo: Itaú Cultural, 2008.

SAFATLE, V. Quando as ruas queimam: manifesto pela emergência. São Paulo: n-1 Edições, 2016. (Série Pandemia)

SARRAZAC, J-P. (Org.). Léxico do drama moderno e contemporâneo. Tradução André Telles. São Paulo: Cosac Naify, 2012.

SCHWARZ, R. O pai de família e outros estudos. Rio de Janeiro: Paz e Terra, 1978. SILVA, T. T. (Org.). Liberdades reguladas: a pedagogia construtivista e outras formas de governo do eu. Petrópolis: Vozes, 1998. 
SINGER, A. Brasil, junho de 2013: classes e ideologias cruzadas. Novos Estudos, n. 97, p. 22-40, nov. 2013.

SOUZA, G. M. Exercícios de leitura. São Paulo: Duas Cidades, 1980.

STAROBINSKI, J. A melancolia diante do espelho: três leituras de Baudelaire. Tradução Samuel Titan Jr. São Paulo: Editora 34, 2014.

SZYMBORSKA, W. Poemas. Seleção e tradução Regina Przybycien. São Paulo: Companhia das Letras, 2011.

WILLIAMS, R. Base e superestrutura na teoria cultural marxista. Tradução Bianca

Ribeiro Manfrini. Revisão Maria Elisa Cevasco. Revista USP, n. 65, p. 210-224, mar./maio 2015.

ŽlŽEK, S. O ano em que sonhamos perigosamente. Tradução Rogério Bettoni. São Paulo: Boitempo, 2012.

ZUPANCIC, A. Sexo, ontologia e subjetividade. Tradução Daniel Alves Teixeira. Lavra-

Palavra, 1 mar. 2016. Entrevista concedida a Randall Terada. Disponível em: <https://lavrapalavra.com/2016/03/01/sexo-ontologia-e-subjetividade/>. Acesso em: 13 ago. 2016.

Recebido em 07/09/2016 Aprovado em 28/10/2016

Publicado em 21/12/2016 